Organization. The Conference of the Pacific Community is the governing body of the Community. Its key focus is to appoint the Director-General, to consider major national or regional policy issues and to note changes to the Financial and Staff Regulations approved by the CRGA, the Committee of Representatives of Governments and Administrations. It meets every two years. The CRGA meets once a year and is the principal decision-making organ of the Community. There are also regional offices in the Fiji Islands and Micronesia.

Headquarters: BP D5, 98848 Nouméa Cedex, New Caledonia. Website: http://www.spc.int

Email: spc@spc.int

Director-General: Dr Jimmie Rodgers (Solomon Islands).

\section{South Asian Association for Regional Co-operation (SAARC)}

SAARC was established to accelerate the process of economic and social development in member states. The foreign ministers of the seven member countries met for the first time in New Delhi in Aug. 1983 and adopted the Declaration on South Asian Regional Co-operation whereby an Integrated Programme of Action (IPA) was launched. The charter establishing SAARC was adopted at the first summit meeting in Dhaka in Dec. 1985.

Members. Afghanistan, Bangladesh, Bhutan, India, Maldives, Nepal, Pakistan, Sri Lanka. Observers. Australia, China, EU, Iran, Japan, South Korea, Mauritius, Myanmar, USA.

Objectives. To promote the welfare of the peoples of South Asia; to accelerate economic growth, social progress and cultural development; to promote and strengthen collective self-reliance among members; to promote active collaboration and mutual assistance in the economic, social, cultural, technical and scientific fields; to strengthen co-operation with other developing countries and among themselves. Co-operation within the framework is based on respect for the principles of sovereign equality, territorial integrity, political independence, non-interference in the internal affairs of other states and mutual benefit. Agreed areas of co-operation under the Integrated Programme of Action (IPA) include agriculture and rural development; human resource development; environment, meteorology and forestry; science and technology; transport and communications; energy; and social development.

A SAARC Preferential Trading Arrangement (SAPTA) designed to reduce trade tariffs between SAARC member states was signed in April 1993, entering into force in Dec. 1995. In 1998 at the Tenth Summit in Colombo, the importance of achieving a South Asian Free Trade Area (SAFTA) as mandated by the Malé Summit in 1997 was reiterated and it was decided to set up a Committee of Experts to work on drafting a comprehensive treaty regime for creating a free trade area. The Colombo Summit agreed that the text of this regulatory framework would be finalized by 2001 .

Organization. The highest authority of the Association rests with the heads of state or government, who meet annually at Summit level. The Council of Foreign Ministers, which meets twice a year, formulates policy, reviews progress and decides on new areas of co-operation. The Council is supported by a Standing Committee of Foreign Secretaries, by the Programming Committee and by 11 Technical Committees which are responsible for individual areas of SAARC's activities. There is a secretariat in Kathmandu, headed by a Secretary-General, who is assisted in his work by seven Directors, appointed by the Secretary-General upon nomination by member states for a period of three years which may in special circumstances be extended.
Official language: English.

Headquarters: PO Box 4222, Kathmandu, Nepal.

Website: http://www.saarc-sec.org

Secretary-General: Dr Sheel Kant Sharma (India).

\section{Arab Fund for Economic and Social Development (AFESD)}

Established in 1968, the Fund commenced operations in 1974.

Functions. AFESD is an Arab regional financial institution that assists the economic and social development of Arab countries through: financing development projects, with preference given to overall Arab development and to joint Arab projects; encouraging the investment of private and public funds in Arab projects; and providing technical assistance services for Arab economic and social development.

Members. Algeria, Bahrain, Comoros, Djibouti, Egypt, Iraq, Jordan, Kuwait, Lebanon, Libya, Mauritania, Morocco, Oman, Palestine, Qatar, Saudi Arabia, Somalia, Sudan, Syria, Tunisia, United Arab Emirates, Republic of Yemen.

Headquarters: PO Box 21923, Safat 13080, Kuwait.

Website: http://www.arabfund.org

Director General and Chairman of the Board of Directors:

Abdulatif Y. Al Hamad (Kuwait).

Publications. Annual Report; Joint Arab Economic Report.

\section{Arab Monetary Fund (AMF)}

Origin. The Agreement establishing the Arab Monetary Fund was approved by the Economic Council of the League of Arab States in April 1976 and the first meeting of the Board of Governors was held on 19 April 1977.

Aims. To assist member countries in eliminating payments and trade restrictions, in achieving exchange rate stability, in developing capital markets and in correcting payments imbalances through the extension of short- and medium-term loans; the coordination of monetary policies of member countries; and the liberalization and promotion of trade and payments, as well as the encouragement of capital flows among member countries.

Members. Algeria, Bahrain, Comoros, Djibouti, Egypt, Iraq, Jordan, Kuwait, Lebanon, Libya, Mauritania, Morocco, Oman, Palestine, Qatar, Saudi Arabia, Somalia, Sudan, Syria, Tunisia, United Arab Emirates, Republic of Yemen.

Headquarters: PO Box 2818, Abu Dhabi, United Arab

Emirates.

Website: http://www.amf.org.ae

Director General and Chairman of the Board of Directors: Jassim A. Al-Mannai (Bahrain).

Publications (in English and Arabic): Annual Report; The Articles of Agreement of the Arab Monetary Fund; Money and Credit in Arab Countries (annual); National Accounts of Arab Countries (annual); Foreign Trade of Arab Countries (annual); Cross Exchange Rates of Arab Currencies (annual); Arab Countries: Economic Indicators (annual); Balance of Payments and External Public Debt of Arab Countries (annual); AMF Publications Catalogue (annual). (In Arabic only): The Joint Arabic Economic Report (annual); AMF Economic Bulletin; Developments in Arab Capital Markets (quarterly). 